\title{
Use of remote sensing and GIS techniques for groundwater exploration in the basement complex terrain of Ado-Ekiti, SW Nigeria
}

\author{
A. Akinola Oyedele ${ }^{1}$
}

Received: 7 January 2018 / Accepted: 4 March 2019 / Published online: 22 March 2019

(c) The Author(s) 2019

\begin{abstract}
Integrated investigations involving remote sensing and GIS have been conducted with the objective of achieving optimal results in sustainable groundwater development in Ado-Ekiti, south-western Nigeria. The hard rock terrain in the region presents challenges in groundwater exploration. Landsat imageries were used for landuse/landcover mapping and lineament analysis for groundwater prospecting. Shuttle Radar Topographic Mission Digital Elevation Model was used for drainage network extraction, slope and geomorphological analysis. Thematic maps were generated, analysed in terms of hydrogeological importance and reclassified for integration using appropriate software. The groundwater potential maps generated were validated against the existing groundwater yield data. The light vegetation and bare soil area cover was $110.9 \mathrm{~km}^{2}$, with the rock outcrops covering a total area of $14.9 \mathrm{~km}^{2}$. Hydrogeomorphic units delineated included hills, pediments, pediplains, alluvium and valley fills. The lineaments showed predominantly NNW-SSE, ENE-WSW and NNE-SSW orientations and subsidiary NW-SE and W-E trends. Application of geospatial techniques has been recognized. The methodology provides improvements in the understanding of the hydrogeological characteristics of the basement terrain. These will aid planning and management of groundwater resources in the crystalline basement terrain.
\end{abstract}

Keywords Basement complex $\cdot$ Geomorphology $\cdot$ Groundwater potential $\cdot$ Lineament extraction

\section{Introduction}

Ado-Ekiti metropolis is underlain by the hydrogeologically challenging crystalline basement rocks whose hydraulic properties are characterized by extreme variations over short distances which often limit groundwater development to low-yielding well. High borehole failure rate has been reported in the area (Olayinka 1992; Fashae et al. 2014; Ojo et al. 2015).

Ogundana et al. (2015) reported high borehole failure of ten (representing 71\%) out of fourteen boreholes studied at ABUAD in the metropolis. These boreholes exhibit low groundwater yield as the holes could not support continuous flow of water beyond $5 \mathrm{~min}$. Bayowa et al. (2014) attributed the high borehole failure rate in the area to inadequate

A. Akinola Oyedele

akinakin02@yahoo.com

1 Department of Physics, Ekiti State University, Ado-Ekiti, Nigeria knowledge of the hydrogeological characteristics of the hard rock terrain. Forkuor et al. (2013) emphasized the need for thorough pre-drilling hydrogeological investigations. These and similar studies underlined the need for improvements in the conventional methodology to ensure optimum results in groundwater development.

The occurrence and circulation of groundwater is controlled by geological factors. The crystalline basement rocks only possess secondary porosity arising from joints, fissures/fractures and intergranular porosity (Olayinka 1992; Amadi and Olasehinde 2010; Ojo et al. 2015). Satellitebased remote sensing data are capable of revealing structural features including faults, fractures and different landforms. Singh et al. (2013), Ndatuwong and Yadav (2014) and Badamasi et al. (2016) emphasized the usefulness of remote sensing as a rapid assessment tool in groundwater exploration. The integrated approach is particularly fascinating as it is applicable even in inaccessible areas. Groundwater is expected to form a significant part of the water resources of Ado-Ekiti and its environs.

The thrust of this work is to apply geospatial techniques to provide information on the hydrogeological regime of a 
typical hard rock terrain with a view to achieving optimal result in sustainable groundwater development in Ado-Ekiti.

\section{Description and geology of the study area}

Ado-Ekiti, south-western Nigeria, lies within latitudes $7^{\circ} 33^{\prime}$ and $7^{\circ} 42^{\prime} \mathrm{N}$ and longitudes $5^{\circ} 11^{\prime}$ and $5^{\circ} 20^{\prime} \mathrm{E}$ (Fig. 1). The topography of the area is fairly rugged (Fig. 2). The area falls within the basement complex of south-western Nigeria (Rahaman 1988). The rock sequence includes granitite rocks, charnockitic rocks, the quartzite series, gneisses and migmatites (Fig. 3).

The region experiences a tropical climate with mean annual temperature of $27{ }^{\circ} \mathrm{C}$ and distinct wet and dry seasons. About $75 \%$ of all rainfall events are of moderate to high intensities. Light showers of less than $10 \mathrm{~mm} / \mathrm{h}$ account for only $25 \%$. The major rivers draining the area include Alamoji, Elemi and Ireje (Olajuyigbe 2010; Bankole 2010).

\section{Materials and methods}

Landsat enhanced thematic mapper (ETM +) sensor of path 190 and row 055 acquired in 2005 was used for lineament extraction. PCI Geomatica 2013 was used for automatic lineament extraction with ArcGIS 10.2.2. Rockware 15 was used for generating lineament statistics.

Shuttle Radar Topographic Mission Digital Elevation Model (SRTM DEM) was used for drainage network extraction, slope and geomorphological analysis. ArcHydro module was employed for drainage network extraction. Geomorphological and slope maps were prepared. Topographic analyses were carried out on the DEM including sink fill, flow direction, flow accumulation, stream order and stream to feature. The fill tool in the spatial analyst of Arcmap was used to fill the sink and remove peaks within the data (Hung et al. 2005; Singh et al. 2013).

Landuse/landcover (LULC) map of the study area was produced using Landsat 8 imagery of path 190 and row 055 acquired in 2015. Ecognition Developer software was used for image classification.

Other data inputs are Geological map 3300/6/66/3289/OS prepared by the British Government Ministry of Overseas Development on 1:250,000 scale and Topographical sheet 1000/404/6.68 compiled and drawn by Federal Survey from photo reduction 244 (Ado-Ekiti), 245 (Ikole), 264 (Akure) and 265 (Owo).

Data preparation (mainly digitizing), data pre-processing (georeferencing and resampling), data processing [edge detection and principal components analysis (PCA)], data analysis and integration (lineament extraction and statistics, geostatistical analysis, IDW) formed the basic methodology of this study (Hung et al. 2005; Prasad et al. 2013).

The thematic layers of the extracted features including lithology, geomorphology, drainage density, slope, lineaments and landuse/landcover were generated and reclassified in terms of hydrogeological importance. Weightage factors were assigned to themes and their corresponding categories according to the groundwater prospects. The reclassified layers were integrated in a GIS environment to produce a composite groundwater potential map of the study area. The generated groundwater potential zones were validated with field checks and the existing groundwater yield data (Hammouri et al. 2012; Singh et al. 2013; Fashae et al. 2014). The flow chart is presented in Fig. 4.

\section{Results and discussion}

The results are presented as maps and tables. Six parameters were evaluated, namely lithology, lineament density, drainage density, geomorphology, slope and LULC.

\section{Geology/lithology}

The dominant lithologies in the study area include migmatites, gneisses, granite, quartzite and charnockite (Fig. 3). The granitic rocks occupy the western and north-central parts, the charnockitic rocks are found in the central, while the gneisses and migmatites occur in the western and eastern flanks. The quartzite occurrences are located in the western and central portion as elongated bodies within the granitic and coarse-grained charnockitic rocks (Ayodele and Aturamu 2011; Rahaman 1988).

\section{Lineament analysis}

The results of the lineament analysis are presented as the lineament map (Fig. 5) and lineament density map (Fig. 6). Lineaments are indicative of zones of localized weathering which are known for high permeability and porosity. These features enhance groundwater accumulation (Prasad et al. 2008; Prabu and Rajagopalan 2013; Fashae et al. 2014).

The lineaments show mainly NNW-SSE, ENE-WSW and NNE-SSW orientations with subsidiaries along NW-SE and $\mathrm{W}-\mathrm{E}$. The orientation of the fractures is indicative of the preferential flow path (Talabi and Tijani 2011; Ojo et al. 2015). The majority of the lineaments/fractures are located on the migmatized biotite-hornblende gneiss with the minorities on the charnockites. The distribution of lineaments suggests geologic control. The granites and gneisses are more responsive to stress by fracturing than charnockites. 


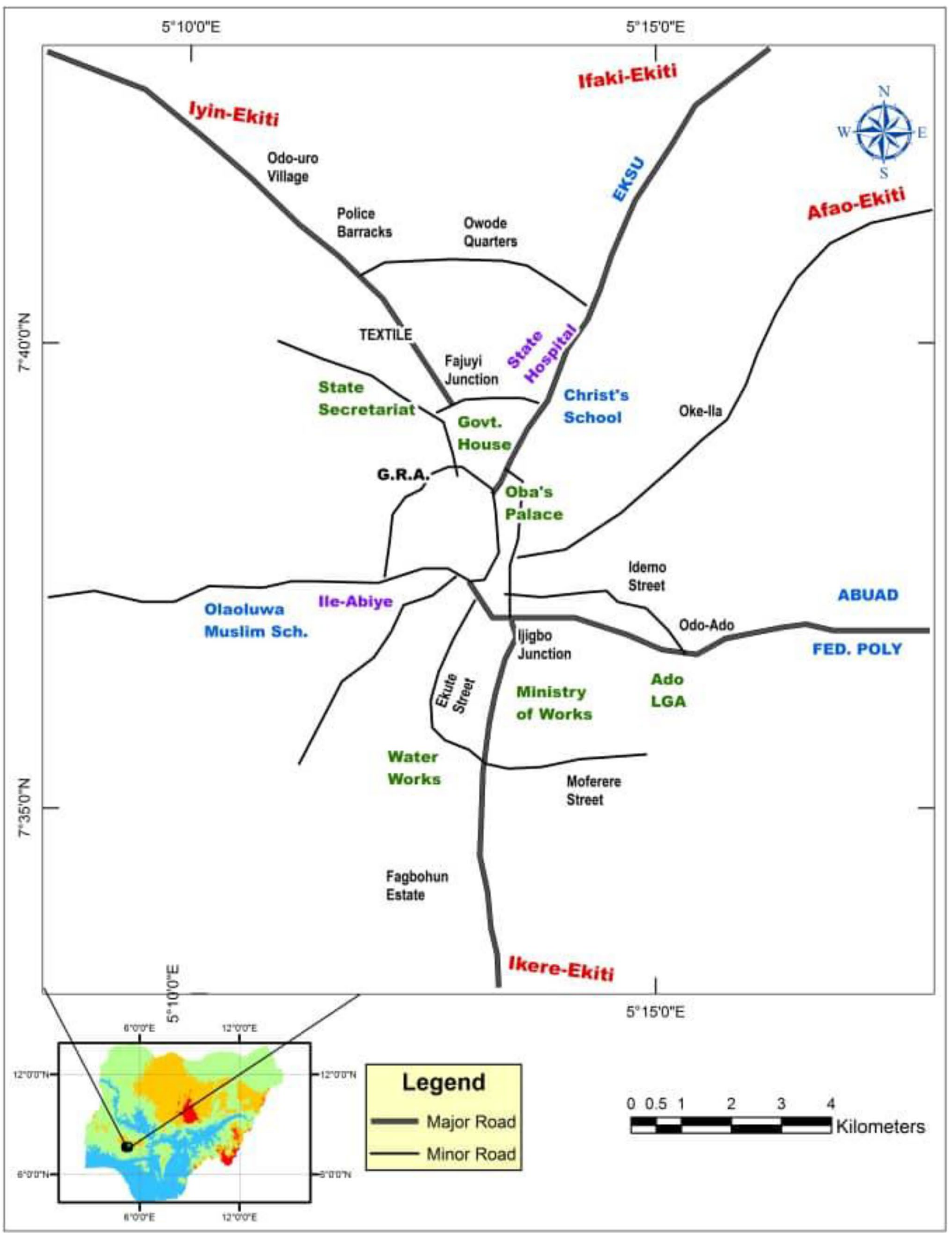

Fig. 1 Location map of Ado-Ekiti — the study area. Adapted from Google map 


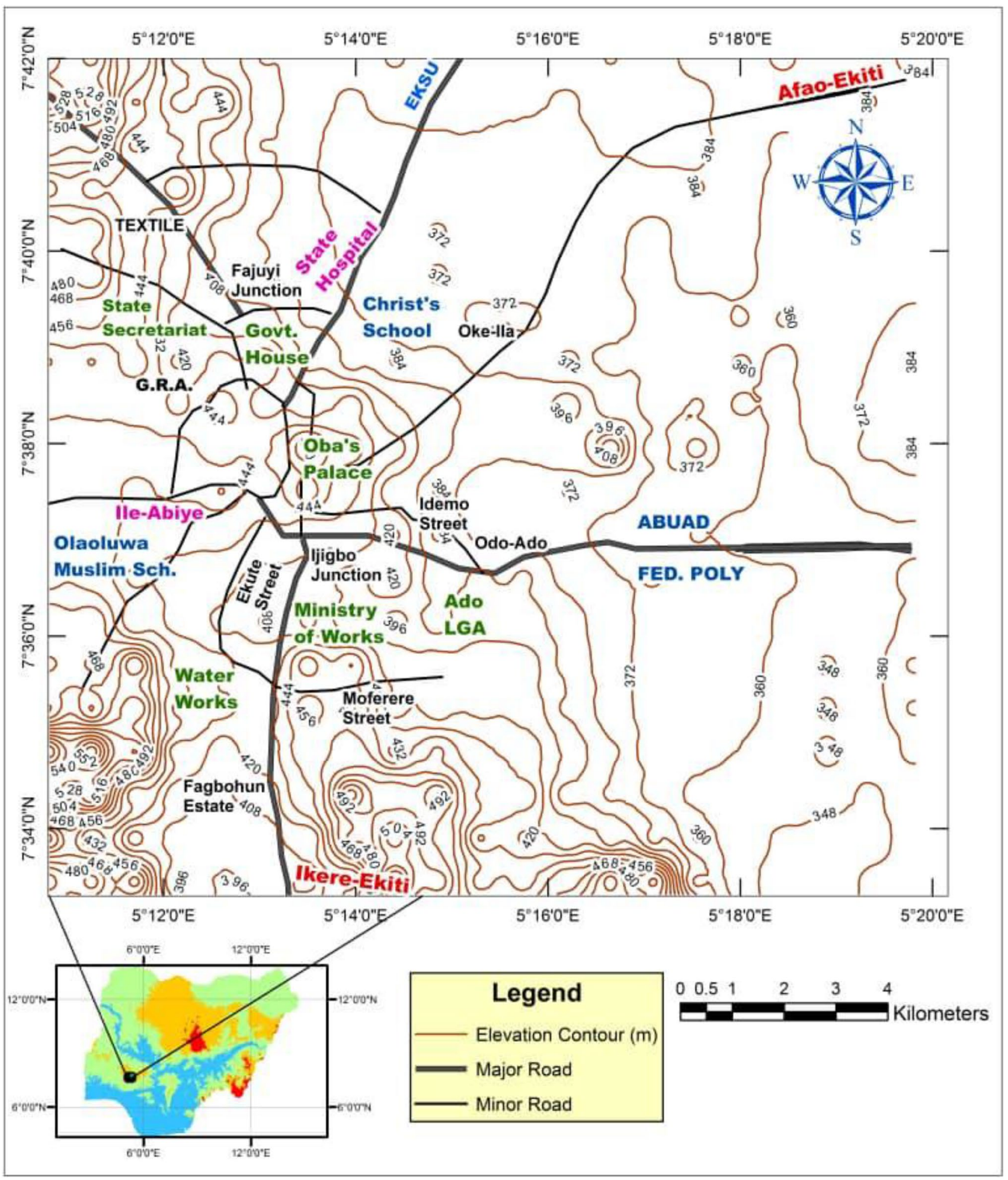

Fig. 2 Topographical map of Ado-Ekiti. Adapted from Google map 


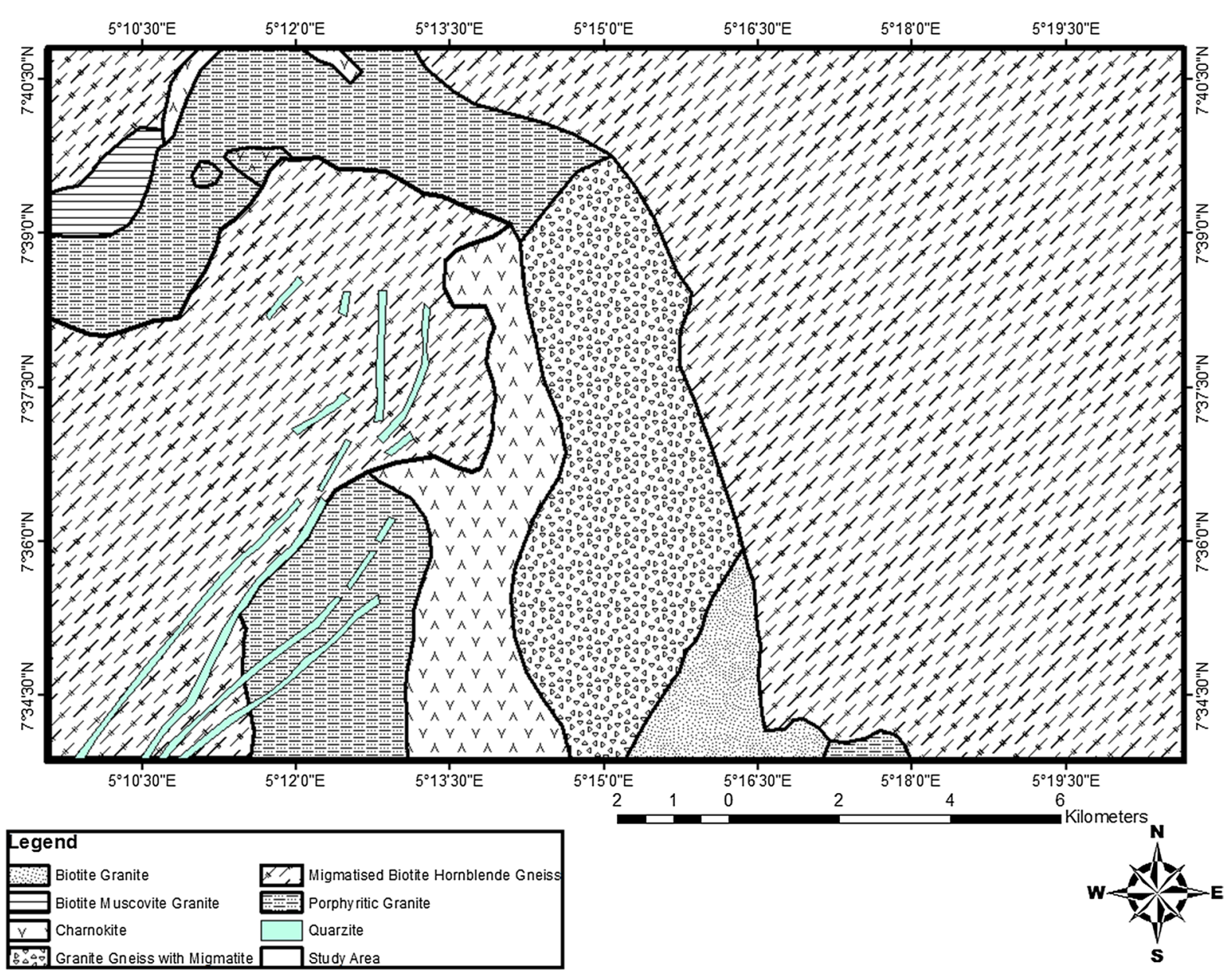

Fig. 3 Geological map of Ado-Ekiti. After NGSA; Geological map of Akure Sheet 56, 1966

Fig. 4 The processing flow chart

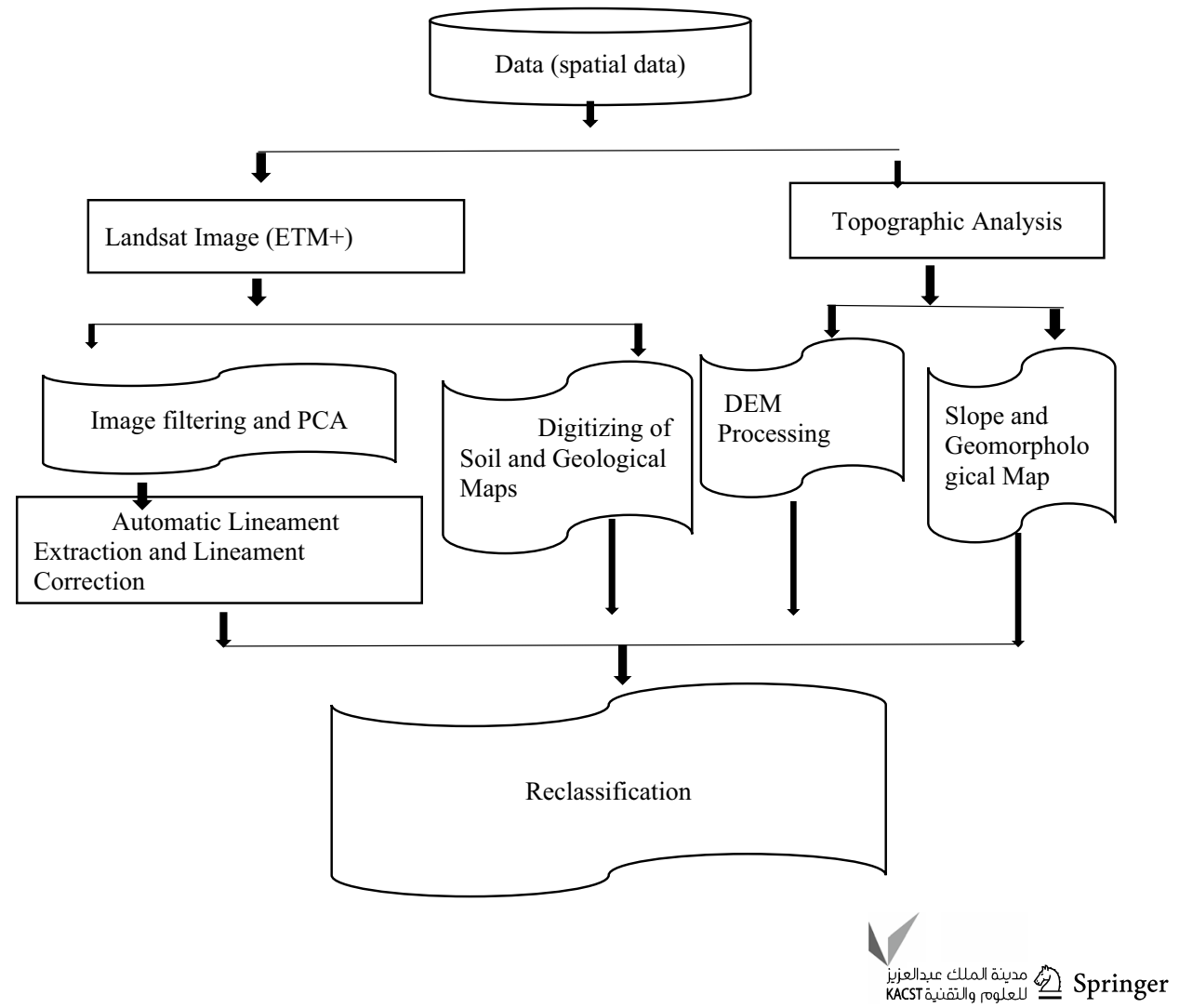




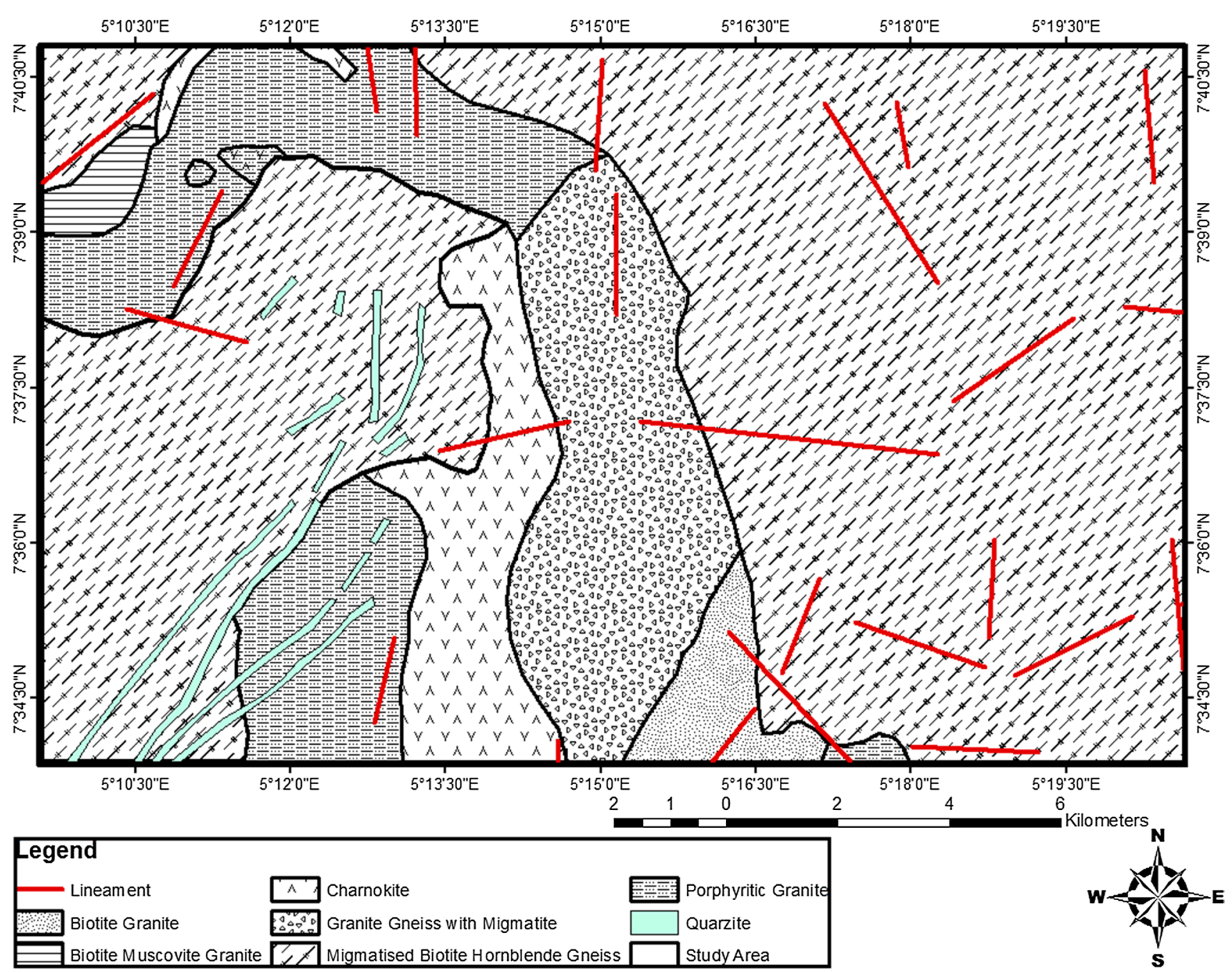

Fig. 5 Lineament map of the study area

High groundwater potentials are thus envisaged from areas underlain by gneisses and granites (Olorunfemi et al. 1999; Chuma et al. 2013).

Groundwater potential could be inferred from lineament density of an area (Ghosh et al. 2016). The lineaments density map shows the lineament numbers to be in the range of 0.00 and $0.24 \mathrm{~km} / \mathrm{km}^{2}$. The result is consistent with Fashae et al. (2014) which observed lineament density varying from less than 0.04 to $0.35 \mathrm{~km} / \mathrm{km}^{2}$ across the Basement Complex terrain of south-western Nigeria. High lineaments density suggests high groundwater potential (Chuma et al. 2013; Prabu and Rajagopalan 2013; Ojo et al. 2015).

\section{The hydrogeomorphological map}

Geomorphology reflects various landforms and topographical features in the area of study. These include hills, ridges, pediments, pediplains, pediplain with alluvium and valley fills (Fig. 7). The characteristics and groundwater prospects of the units are given in Table 1. The hills in the area are mainly made up of quartzites, gneisses, granites and charnockites. Groundwater occurs under unconfined conditions in shallow, moderately weathered zones of the pediplain and in semi-confined conditions in joints, fissures, and fractures that extend beyond the weathered zones (Jayeoba and 


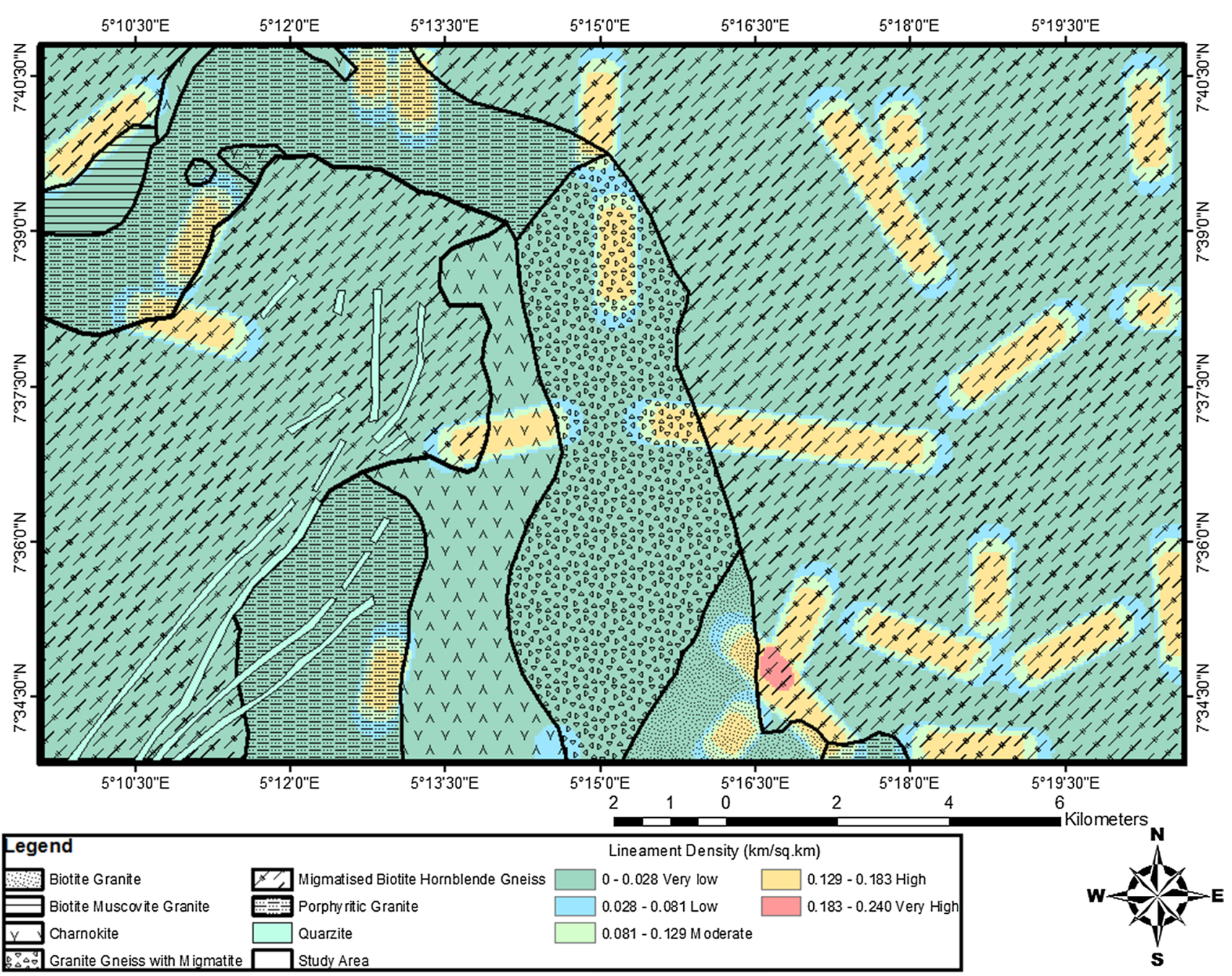

Fig. 6 Lineament density map of the study area

Oladunjoye 2013). Areas within the valley fills, the pediplain with alluvium, pediplains, pediment and hills and ridges portend very high, high, moderate, low and very low groundwater prospect, respectively (Rao and Jugran 2003; Bayowa et al. 2014; Ojo et al. 2015).

\section{Slope}

Surface gradients ranging from $0^{\circ}$ to $49^{\circ}$ observed in the study area (Fig. 8) yielded topographic slopes classes of nearly level, very gentle, gentle, moderate, strong, moderately steep to steep and very steep. The relationship with groundwater potential is presented in Table 2. Steep slope areas are characterized by high run-off, with less residence time for rainwater and less infiltration, while gentle slopes facilitate more time for rainwater infiltration (Prasad et al. 2008; Talabi and Tijani 2011; Bagyaraj et al. 2013).

\section{Landuse/landcover}

Spatial variation in the amount of groundwater storage occurs due to changes in landuse and vegetation cover. Landuse/landcover thus plays a significant role in the recharge process (Fashae et al. 2014; Selvam et al. 2014; Ghosh et al. 2016).

The landuse/landcover classes in the study area are vegetation, water body, built-up and outcrops as shown in Fig. 9. Built-up land (dense, medium and sparse residential areas) comprises $68.6 \mathrm{~km}^{2}$ of the total study area. Coverage of $52.4 \mathrm{~km}^{2}, 13.5 \mathrm{~km}^{2}$ and $2.7 \mathrm{~km}^{2}$ is recorded for dense, 


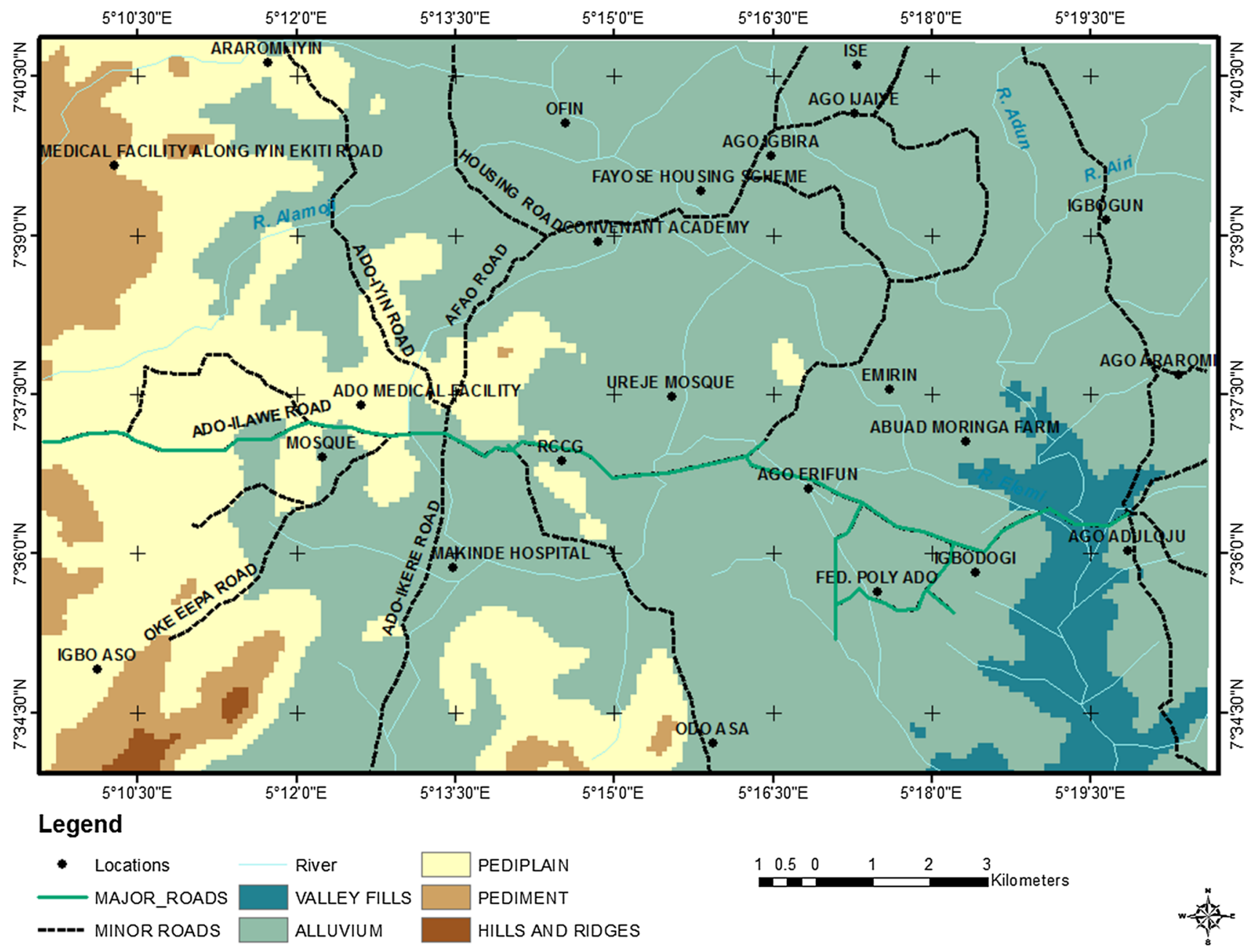

Fig. 7 Hydrogeomorphological map of the study area

Table 1 Hydrogeomorphological characteristics in Ado-Ekiti (Rao and Jugran 2003; Talabi and Tijani 2011)

\begin{tabular}{|c|c|c|}
\hline Units & Characteristics & Groundwater prospects \\
\hline Alluvium & $\begin{array}{l}\text { Nearly level surface adjoining river courses with intercalations of gravel, } \\
\text { coarse-fine sand, clay, etc. }\end{array}$ & Very good to excellent \\
\hline Moderately weathered pediplain & $\begin{array}{l}\text { Occurring away from hills with gentle slopes and appreciable vegetation } \\
\text { cover. The potentials are increased when underlain by fractures with } \\
\text { increased weathered zone thickness }\end{array}$ & Good to very good \\
\hline Shallow weathered pediplain & $\begin{array}{l}\text { Gentle to medium slope with sparse vegetation; possess only medium } \\
\text { groundwater prospect unless when underlain by fractures }\end{array}$ & Medium to good \\
\hline Inselberg, residual hill and denudational hill & $\begin{array}{l}\text { characterized by medium to high relief/steep slopes with varying area } \\
\text { extent or dimensions }\end{array}$ & Nil \\
\hline The valley fills & $\begin{array}{l}\text { Consist of weathered materials and in-filling of unconsolidated materials } \\
\text { in the valley areas; usually underlain by fractures }\end{array}$ & Very good \\
\hline
\end{tabular}




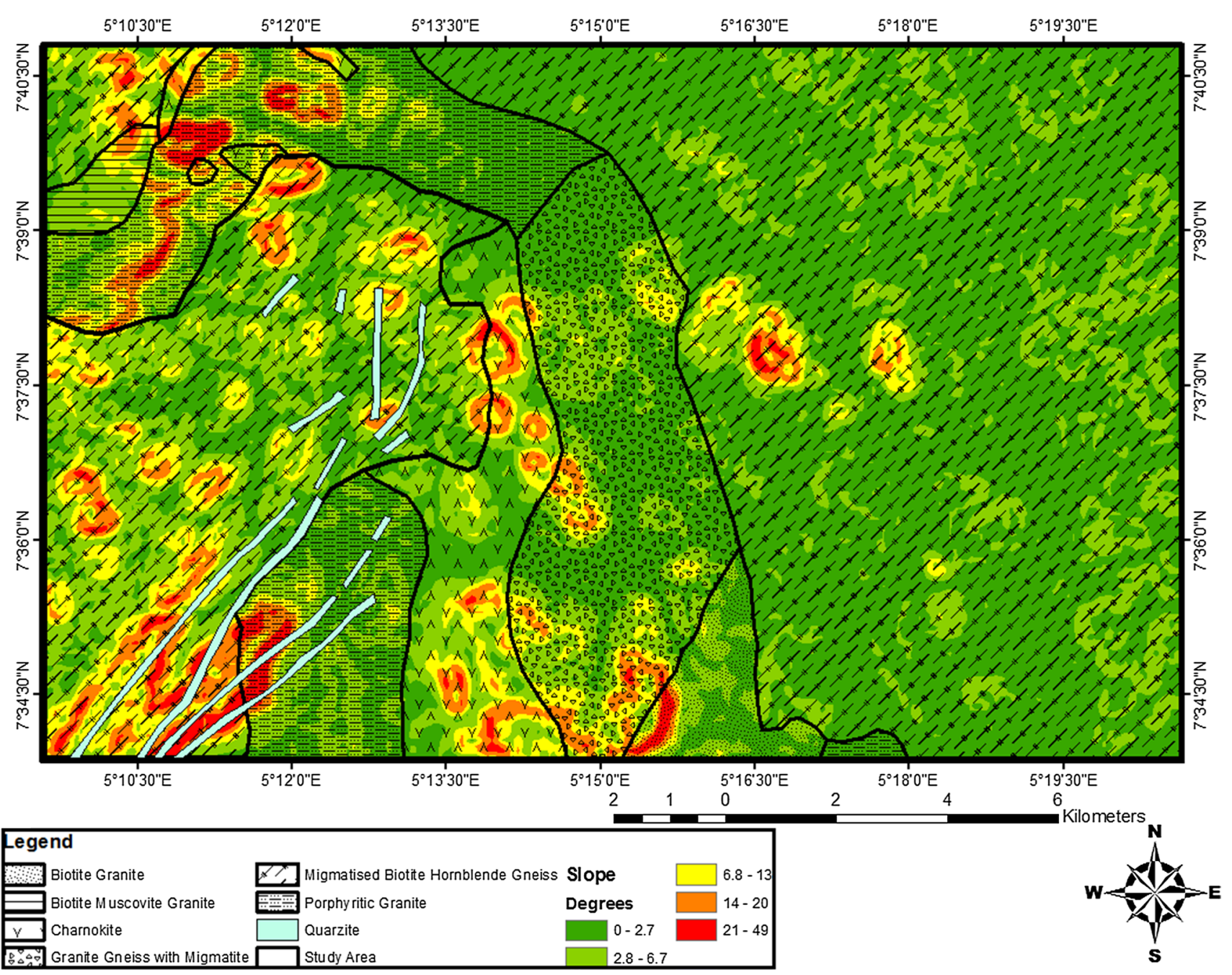

Fig. 8 Slope map of the study area

Table 2 Classification of slope in the study area (Talabi and Tijani 2011)

\begin{tabular}{lll}
\hline Classes & Attributes & Groundwater prospect \\
\hline $0^{\circ}-2.7^{\circ}$ & Gently sloping & Very high \\
$2.8^{\circ}-6.7^{\circ}$ & Moderately sloping & High \\
$6.8^{\circ}-13^{\circ}$ & Moderate steep sloping & Medium \\
$14^{\circ}-20^{\circ}$ & Steep sloping & Low \\
$>20^{\circ}$ & Very steeply sloping & Very low \\
\hline
\end{tabular}



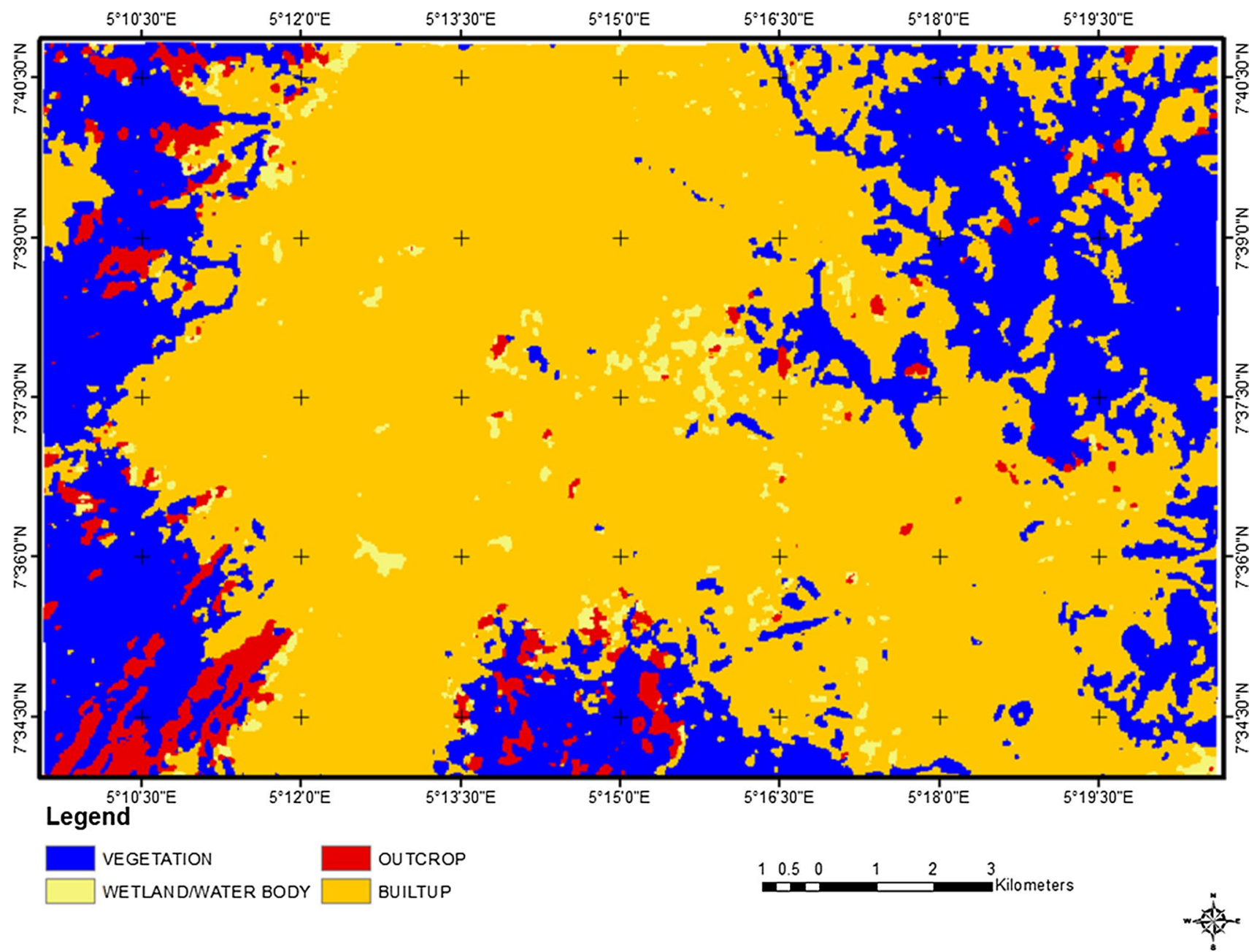

Fig. 9 Landuse/landcover map of the study area

medium and sparse residential areas, respectively. The light vegetation/bare soil has an area extent of $110.9 \mathrm{~km}^{2}$ with the outcrops located in the north-western and south-western parts covering a total area of $14.9 \mathrm{~km}^{2}$. The barren/fallow lands and settlements would have poor water-holding capacity unlike the wet/water bodies and cultivated lands (Selvam et al. 2014; Badamasi et al. 2016; Ghosh et al. 2016).

\section{Drainage network/density}

The drainage pattern, in general, is dendritic, typical of a granitic terrain. The drainage network analysis is germane to evaluate the recharge property. It is indicative of the rate of water percolation. The drainage density is proportional to surface run-off. Low drainage density enhances recharge and groundwater prospects (Shaban et al. 2006; Prasad et al. 2008; Selvam et al. 2014). On the stand point of recharge/groundwater prospect, more weightage has been assigned to regions of very low drainage density, while low weightage was assigned to regions of very high drainage density.

\section{Groundwater potential evaluation (based on RS-GIS)}

The spatial analysis and modelling involves integration of lithology, lineament density, drainage density, geomorphology, slope and LULC thematic layers. Weights ranging from 1 to 5 were assigned to the classes with respect to groundwater prospect in ascending order. The thematic maps were 
Table 3 Weighting combination for groundwater potential zonation

\begin{tabular}{|c|c|c|c|}
\hline Parameters & Classes & Scale value & Rank \\
\hline \multirow[t]{5}{*}{ Lineament density } & Very low & 1 & 20 \\
\hline & Low & 2 & \\
\hline & Medium & 3 & \\
\hline & High & 4 & \\
\hline & Very high & 5 & \\
\hline \multirow[t]{5}{*}{ Drainage density } & Very low & 5 & 15 \\
\hline & Low & 4 & \\
\hline & Medium & 3 & \\
\hline & High & 2 & \\
\hline & Very high & 1 & \\
\hline \multirow[t]{5}{*}{ Geomorphology } & Valley fills & 5 & 15 \\
\hline & Alluvium & 4 & \\
\hline & Pediplain & 3 & \\
\hline & Pediment & 2 & \\
\hline & Hill and ridges & 1 & \\
\hline \multirow[t]{7}{*}{ Geology } & Variably migmatized undifferentiated biotite-hornblende-gneiss & 1 & 20 \\
\hline & Charnockite meta intrusive & 1 & \\
\hline & Undifferentiated older granite mainly granitized gneiss & 3 & \\
\hline & Coarse porphyritic biotite and biotite-hornblende & 3 & \\
\hline & Fine- to medium-grained biotite and biotite-muscovite granite & 3 & \\
\hline & Medium- to coarse-grained biotite granite & 3 & \\
\hline & Quartzite vein & 5 & \\
\hline \multirow[t]{5}{*}{ Slope } & Very gentle & 5 & 15 \\
\hline & Gentle & 4 & \\
\hline & Medium & 3 & \\
\hline & Steep & 2 & \\
\hline & Very steep & 1 & \\
\hline \multirow[t]{4}{*}{ Landuse/landcover } & Outcrop & 3 & 15 \\
\hline & Wetland/waterbody & 1 & \\
\hline & Built-up & 3 & \\
\hline & Vegetation & 5 & \\
\hline
\end{tabular}

synthesized in a GIS environment using weighted indices for groundwater potential map development according to the works of Rao and Jugran (2003), Talabi and Tijani (2011) and Fashae et al. (2014). The resulting groundwater potential possibility maps were subjected to validation against the existing borehole yield data. The weighting combination (Table 3) which gave the highest correlation was subsequently adopted, thereby producing the groundwater potential map (Fig. 10). The map classifies the study area into very low, low, moderate and high groundwater potential zones.

The marked variability and the unpredictability of the nature of basement aquifers suggest that precision is essential as a location error of less than $5 \mathrm{~m}$ can make all the difference between a productive borehole and a dry hole.
Tube wells drilled without sequential hydrogeological and geophysical study often fail to meet the quest for groundwater and justify the overall cost (Olayinka 1992; Fashae et al. 2014).

The integrated RS-GIS analysis offers an approach that narrows down the target areas for detailed hydrogeophysical exploration (Bagyaraj et al. 2013; Prabu and Rajagopalan 2013; Ndatuwong and Yadav 2014). Site-specific ground geophysical methods such as the very low frequency electromagnetic (VLF-EM) profiling and vertical electrical sounding (VES) could then be deployed for site characterization and selection for sustainable groundwater development. 


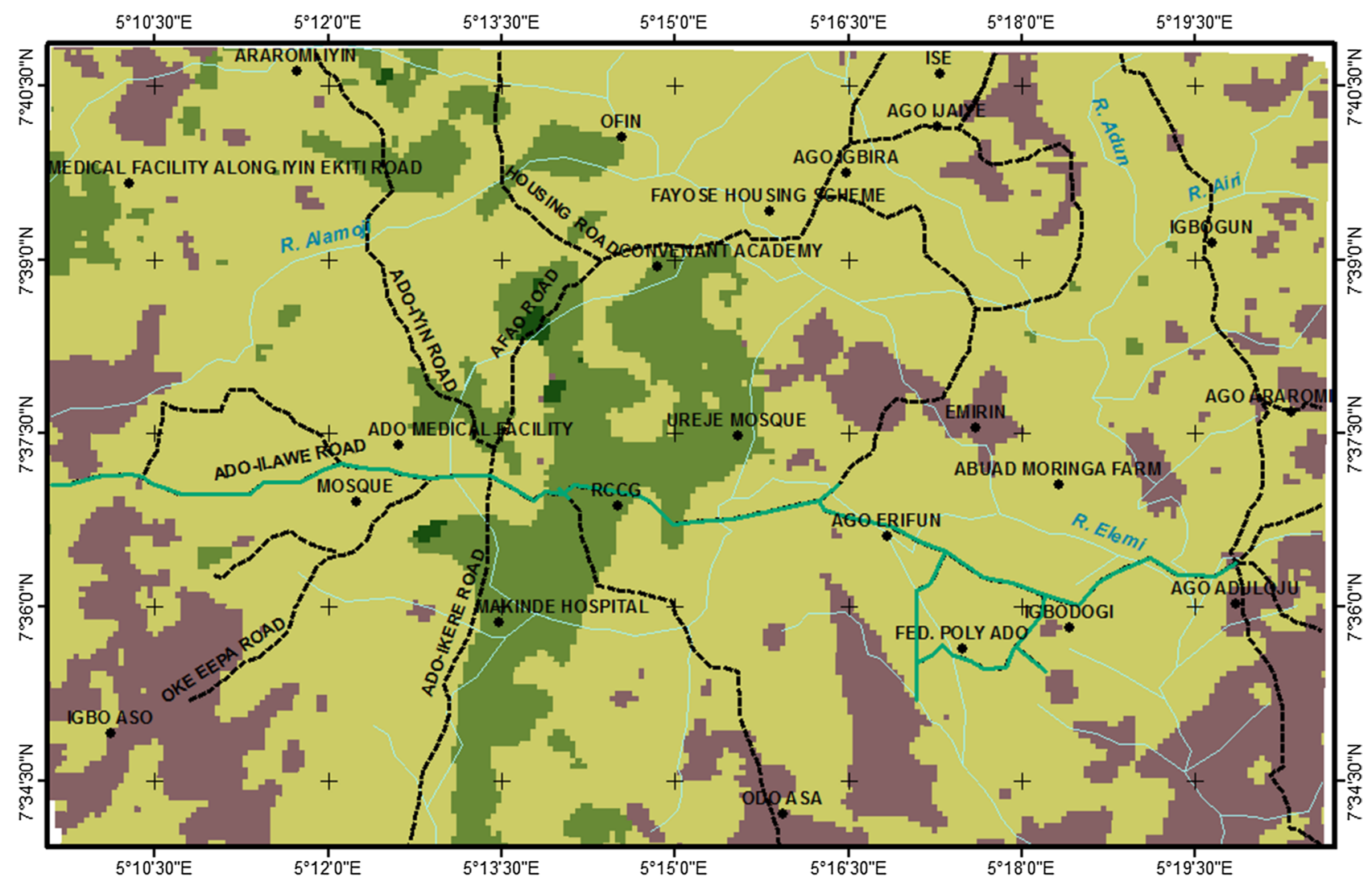

\section{Legend GROUNDWATER POTENTIALZONE}

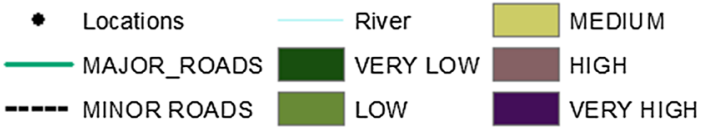

Fig. 10 Groundwater potential map of the Ado-Ekiti area, SW, Nigeria

\section{Conclusions}

The study delineated very low, low, moderate and high groundwater potential zones. The groundwater resources in hard rock terrain are limited and commonly restricted to diastrophic features. Groundwater exploration in the terrain demands precise determination of the attributes of these features. Remote sensing-GIS approach would serve as the preliminary inventory method to understand groundwater potential index and facilitate delineation of zones adjudged suitable for further hydrogeophysical investigations.

Acknowledgements All sources of data for this work are acknowledged with thanks. The useful suggestions of the Editor-in-Chief and the anonymous reviewers are appreciated.

\section{Compliance with ethical standards}

Conflict of interest I hereby state that there is no conflict of interest of any sort on this work. Potential conflicts do not exist regarding the work.

Open Access This article is distributed under the terms of the Creative Commons Attribution 4.0 International License (http://creativeco mmons.org/licenses/by/4.0/), which permits unrestricted use, distribution, and reproduction in any medium, provided you give appropriate credit to the original author(s) and the source, provide a link to the Creative Commons license, and indicate if changes were made.

\section{References}

Amadi AN, Olasehinde PI (2010) Application of remote sensing techniques in hydrogeological mapping of parts of Bosso Area, Minna, North-Central Nigeria. Int J Phys Sci 5(9):1465-1474 
Ayodele OS, Aturamu AO (2011) Potability status of some hand dug wells in Ekiti State, southwestern Nigeria. Int J Sci Technol 1(2):102-109

Badamasi S, Sawa BA, Garba ML (2016) Groundwater potential zones mapping using remote sensing and geographic information system techniques (GIS) in Zaria, Kaduna State, Nigeria. Am Sci Res J Eng Technol Sci 24(1):51-62

Bagyaraj M, Ramkumar T, Venkatramanan S, Gurugnanam B (2013) Application of remote sensing and GIS analysis for identifying groundwater potential zone in parts of Kodaikanal Taluk, South India. Front Earth Sci 7(1):65-75

Bankole BO (2010) The geographical distribution of water supply in Ekiti State. Afr Res Rev 4(2):71-79

Bayowa OG, Olorunfemi OM, Akinluyi OF, Ademilua OL (2014) A preliminary approach to the groundwater potential appraisal of Ekiti State, southwestern Nigeria. Int J Sci Technol 4(3):48-58

Chuma C, Orimoogunje OOI, Hlatywayo DJ, Akinyede JO (2013) Application of remote sensing and geographical information systems in determining the groundwater potential in the crystalline basement of Bulawayo metropolitan area, Zimbabwe. Adv Remote Sens 2:149-161

Fashae OA, Tijani MN, Talabi AO, Adedeji OI (2014) Delineation of groundwater potential zones in the crystalline basement terrain of SW-Nigeria: an integrated GIS and remote sensing approach. Appl Water Sci 4:19-38

Forkuor G, Pavelic P, Asare E, Obuobie E (2013) Modelling potential areas of groundwater development for agriculture in northern Ghana using GIS/RS. Hydrol Sci J 58(2):437-451

Ghosh PK, Bandyopadhyay S, Jana NC (2016) Mapping of groundwater potential zones in hard rock terrain using geoinformatics: a case of Kumari watershed in western part of West Bengal. Model Earth Syst Environ 2:1-12

Hammouri N, Ali El-Naqa A, Barakat M (2012) An integrated approach to groundwater exploration using remote sensing and geographic information system. J Water Resour Prot 4:717-724

Hung LQ, Batelaan O, De Smedt F (2005) Lineament extraction and analysis, comparison of LANDSAT ETM and ASTER imagery. Case study: Suoimuoi tropical karst catchment, Vietnam. In: Proceedings of SPIE remote sensing for environmental monitoring, GIS applications and geology V, vol 5983, p 59830T

Jayeoba A, Oladunjoye MA (2013) Hydro-geophysical evaluation of groundwater potential in hard rock terrain of southwestern Nigeria. RMZ Mater Geoenviron 60:271-285

Ndatuwong G, Yadav GS (2014) Integration of hydrogeological factors for identification of groundwater potential zones using remote sensing and GIS techniques. J Geosci Geomat 2(1):1-16

Ogundana AK, Aladesanmi AO, Okunade A, Olutomilola OO (2015) Causes of borehole failure in complex basement terrains: ABUAD case study, southwestern Nigeria. Am J Eng Res 4(10):192-201
Ojo JS, Olorunfemi MO, Akintorinwa OJ, Bayode S, Omosuyi GO, Akinluyi FO (2015) GIS integrated geomorphological, geological and geoelectrical assessment of the groundwater potential of Akure Metropolis, southwest Nigeria. J Earth Sci Geotech Eng 5(14):85-101

Olajuyigbe AE (2010) Sustainable water service delivery: an assessment of a water agency in a rapidly Urbanizing City in Nigeria. $J$ Sustain Dev 3(4):210-219

Olayinka AI (1992) Geophysical siting of boreholes in crystalline basement areas of Africa. J Afr Earth Sc 14:197-207

Olorunfemi MO, Ojo JS, Akintunde OM (1999) Hydrogeophysical evaluation of the groundwater potential of Akure metropolis, South-Western Nigeria. J Minin Geol 35(2):207-228

Prabu P, Rajagopalan B (2013) Mapping of lineaments for groundwater targeting and sustainable water resource management in hard rock hydrogeological environment using RS-GIS. Clim Change Reg Local Responses 10:235-247

Prasad RK, Mondal NC, Banerjee P, Nandakumar MV, Singh VS (2008) Deciphering potential groundwater zone in hard rock through the application of GIS. Environ Geol 55(3):467-475

Prasad AD, Jain K, Gairola A (2013) Mapping of lineaments and knowledge base preparation using geomatics techniques for part of the Godavari and Tapi basins, India: a case study. Int J Comput Appl 70(9):39-47

Rahaman MA (1988) Recent advances in the study of the basement complex of Nigeria. In: Precambrian geology of Nigeria. Geological Survey of Nigeria, Kaduna South, pp 11-43

Rao YS, Jugran DK (2003) Delineation of groundwater potential zones and zones of groundwater quality suitable for domestic purposes using remote sensing and GIS. Hydrol Sci J 48(5):821-833

Selvam S, Magesh NS, Sivasubramanian P, Soundranayagam JP, Manimaran G, Seshunarayana T (2014) Deciphering of groundwater potential zones in Tuticorin, Tamil Nadu, using remote sensing and GIS techniques. J Geol Soc India 84:597-608

Shaban A, Khawlie M, Abdallah C (2006) Use of remote sensing and GIS to determine recharge potential zones: the case of Occidental Lebanon. Hydrogeol J 14(4):433-443

Singh P, Thakur JK, Kumar S (2013) Delineating groundwater potential zones in a hard-rock terrain using geospatial tools. Hydrol Sci J 58(1):213-223

Talabi AO, Tijani MN (2011) Integrated remote sensing and GIS approach to groundwater potential assessment in the basement terrain of Ekiti area southwestern Nigeria. RMZ Mater Geoenviron 58(3):303-328

Publisher's Note Springer Nature remains neutral with regard to jurisdictional claims in published maps and institutional affiliations. 